Florida International University FIU Digital Commons

\title{
The research and the creation of a stage manager's book for "The sound of music" musical tour show
}

Nathan Gad Cohen

Florida International University

DOI: $10.25148 /$ etd.FI14060869

Follow this and additional works at: https://digitalcommons.fiu.edu/etd

Part of the Music Commons, and the Theatre and Performance Studies Commons

\section{Recommended Citation}

Cohen, Nathan Gad, "The research and the creation of a stage manager's book for "The sound of music" musical tour show" (2003). FIU Electronic Theses and Dissertations. 2398.

https://digitalcommons.fiu.edu/etd/2398 


\title{
FLORIDA INTERNATIONAL UNIVERSITY
}

\author{
Miami, Florida
}

THE RESEARCH AND THE CREATION OF A STAGE MANAGER'S BOOK FOR "THE SOUND OF MUSIC" - MUSICAL TOUR SHOW

A thesis submitted in partial fulfillment of the

requirements for the degree of

MASTER OF MUSIC

by

Nathan Gad Cohen 
To: Dean Arthur W. Herriott

College of Arts and Sciences

This thesis, written by Nathan Gad Cohen, and entitled The Research and The Creation of a Stage Manager's Book for "The Sound of Music" - Musical Tour Show, having been approved in respect to style and intellectual content, is referred to you for judgment.

We have read this thesis and recommend that it be approved.

Fredrick Kaufman

Steve Welsh

Karen Fuller, Major Professor

Date of Defense: July $24^{\text {th }}, 2003$

The thesis of Nathan Gad Cohen is approved.

Dean Arthur W. Herriott College of Arts and Sciences

Dean Douglas Wartzok Umiversity Graduate School

Florida International University, 2003 


\section{DEDICATION}

I dedicate this thesis to my close family in Israel: Ima \& Avner, Yuval \& Shira, Yonatan, Ben and Dafna, Rami \& Ruti, Maayan and Einav - Bar. Without their love and support throughout the years the completion of this work would not have been possible. 


\section{ACKNOWLEDGMENTS}

I wish to thank Rodgers and Hammerstein's Organization for granting me a limited authorization to use the copyrighted vocal score of "The Sound of Music" (composed by Richard Rodgers and Oscar Hammerstein II) and the copyrighted play script of "The Sound of Music" (written by Iloward Lindsay and Russell Crouse). Special thanks to Robin Walton the Director of Legal Affairs Administration at the Rodgers and Hammerstein's Organization and to Jeremy Nussbaum E.S.Q at the Cowan Liebowitz \& Latman (intellectual property firm) for their consistent cooperation and support. Thanks to R. Handlan the booking coordinator from the Centroplex in Orlando. Thanks to Broward Center for the Performing Arts and the Tampa Bay Performing Arts Center for sharing their facility information and marketing tactics. Many thanks to the Florida International University's Graduate Department for their technical support and to my committee members Fredrick Kaufman (the Director of the School of Music) and Steve Welsh for motivating me to complete my final requisite for the Master of Music degree. Finally, my sincere gratefulness to my Major Professor Karen Fuller for guiding and supporting me throughout the creative process by being so efficient, inspiring and positive. 
ABSTRACT OF THE THESIS

THE RESEARCH AND THE CREATION OF A STAGE MANAGER'S BOOK FOR

"THE SOUND OF MUSIC" - MUSICAL TOUR SHOW

by

Nathan Gad Cohen

Florida International University, 2003

Miami, Florida

Professor Karen Fuller, Major Professor

During the research for the components of a musical production tour company of "The Sound of Music"(Play by Lindsey and Cruze and Music by Rodgers and Hammerstein), the Producer begins with constructing the organizational structure and ascribing essential jobs focusing on the Stage Manager's position and his duties. As an organized and informative leader, the Stage Manager's main responsibility is to create a book which will assist him/her in processing nessessary evolving data into a clear and comunicative information. During the production phases, The Stage Manager's book assists with managing technical and artistic needs using distinctive lists: sound, lights, props, costume, and ground plans. Also, it assists the Stage Manager in prompting sound, light and crew cues from a well-prepared prompt script, which generates smooth rehearsals and performances. Thus, in a large musical capacity the creation of a Stage Manager's book is an inevitable organizational production tool. 
I. INTRODUCTION 1

II. THE MUSICAL'S ORGANIZATIONAL STRUCTURE 3

The structure and hierarchy within the company 3

Figure 1- the organizational structure

The careers involved in a musical touring show

III. THE ESSENTIAL PRODUCTION STAGE MANAGER 12

Table 1- the production schedule $\quad 13$

$\begin{array}{ll}\text { The Production Stage Manager's duties } & 18\end{array}$

IV. "THE SOUND OF MUSIC" - STAGE MANAGER'S BOOK 22

$\begin{array}{ll}\text { V. CONCLUSION } & 379\end{array}$

$\begin{array}{ll}\text { BIBLIOGRAPHY } & 380\end{array}$

$\begin{array}{ll}\text { APPENDIXES } & 381\end{array}$ 


\section{CHAPTER I}

\section{INTRODUCTION}

"Climb every mountain, Ford every stream; Follow every rainbow Till you find your dream." That is the last phrase of the musical "The Sound of Music" (Lyrics by Oscar Hammerstein II music by Richard Rodgers and play written by Howard Lindsay and Russell Crouse.). Being optimistic and cheerful during pleasant and unpleasant adventures on the way to find your real passions in life is the core of the show. The play script is about the life of Maria von Trapp, starting as a postulant at Nonnberg Abbey in Salzburg, Austria. Before Maria joined the abbey she used to hike on mountains and sing for long hours but after becoming a postulant, she constantly would not obey the Abbey's rules, which forced her to quit singing secular songs. The Mother Abbess (spiritual leader of the Abbey) decided to send Maria away for a few months to be a governess for a seven children family. Although Maria wanted to stay at the Abbey she had to respect this decision which eventually was the right decision and changed her life for the best. After Maria became accustomed to the new family and its rules, she conducted singing lessons by teaching songs related to every day life such as My Favorite Things and The Little Goatherd. It didn't take long until the orphaned family adopted her as an inspiring model. The family developed its unity and learned to sing beautifully. Captain von Trapp, after realizing his warm feelings towards Maria, had to dismiss Frau Schrider as his anticipated future wife. Maria also felt the same way for Captain von Trapp but feared being rejected in expressing her feelings. Soon, Maria and the Captain fell in love and were married. After their wedding the family had to cope with the new Nazi regime which forced the Captain to serve in the German Naval force. The determined family didn't give up its dreams and escaped to Italy. Hurried and careful, they set up a plan, which allowed the family to run away through the Abbey's garden to the Italian Alps. During the escape, the family had to hide from a Nazi's military search and fortunately overcame the threatening adventure. 
This almost fantastical, surreal experience was a true event in history. The von Trapps "climbed over the mountains to Italy; from there they traveled to England, then crossed the ocean to America, where they continued to perform"(Hirsch 3). In 1956 Vincent Donehue, a Broadway and a television director that worked for Paramount Pictures, watched the German version of Die Trapp Familie in the Paramount's projection room. He believed that "this would make a great vehicle for Mary Martin" (Hirsch, 4). Mary Martin was his television star for Annie Get Your Gun and the stage and television star for The Skin of Our Teeth. Soon, Donehue, Martin and producer Richard Halliday (Martin's husband) met and decided to produce the story for the Broadway stage. They hired the playwrights and Pulitzer prize winners Howard Lindsay and Russel Crouse and the legendary musical score writers Richard Rodgers and Oscar Hammerstein II. Rodgers and Hammerstein insisted to act as co-producers and as a reward they would write a fresh new musical score. And so, the premier took place at The Lunt-Fontanne Theater in New York, on November 16, 1959 and ran on Broadway for 1,443 performances, won six Tony Awards including Best Musical and sold more than 3 million cast albums.

The artistic and financial success of this show is a wonder in concert and theatrical producing. Considering the tools I have acquired from the Performing Arts Production department in the School of Music at Florida International University, I have decided to research and create a Stage Manager's book with a new analytical artistic approach along with new production and theatrical design elements for this musical. 


\section{THE MUSICAL'S ORGANIZATIONAL STRUCTURE}

Producing, from the very beginning, the Imaginary musical production of "The Sound of Music," requires the acknowledgement of organizational structure. The concept of hierarchy within an organization is essential for multi-functional organization. Certain people will fit into certain jobs. Some are technical, some are administrative, some are managerial and some are labor jobs. Jobs such as loading in and out scenery sets are considered labor and technical jobs, while a light operator, who controls and operates the DMX 512 - lighting console, and a company manager who issues payroll checks, are considered to work in a technical and managerial jobs respectively.

In order to accomplish optimal performance in a multi-functional organization, the theatrical industry dictates through unions that it is necessary to distribute the tasks to several working positions. The distribution of the tasks promotes less stress within the organization and creates a structure in the organization with clear hierarchical positions (chain of command). The structure and hierarchy within the company

The structure depends on the necessities of the organization. "The Sound of Music" production is based on a project of a touring entertainment company. This company has to pay for the costs of producing the show, for instance, rentals of sound equipment and lighting instruments, costume rentals, purchasing materials for scenery, crew and cast salaries, advertisement, PR firm, and insurance. Therefore, the financial responsibility is in the top priority of the organization.

In "The Sound of Music's" company there are three levels of management: strategic, middle and operational. The strategic management type focuses on the plan, policy and the overall operations of the production. The middle management executes the decisions of the strategic management by coordinating and supervising the operational management's 
performances. The operational management is concerned with the day-to-day process of getting the work done and satisfying the middle management's requests.

The Producer and/or the investors are at the top of the strategic management level which hire individuals and companies to fill in the specific functions for the production (see figure 1).

The second tier in "The Sound of Music" structure is also part of the strategic management and is based on the artistic element and the business element. Those elements are the "right and left hands" for the Producer. They assist in putting the show together by supervising and designing the product (the show) and also by supervising the marketing and promotion's campaigns. In the structure they are equally important. The business element is represented by the position of the General Manager and the artistic element is represented by the position of the Artistic Director.

On the third tier of the structure there is the middle management type. It includes managers and contracted companies, which operate the necessary business and artistic functions. In the business area we can find marketing and public relations firms. They are the promoters of the "product" and they plan how to increase ticket's sale and pursue it. The accounting firm is also part of the business department. It processes financial data into clear information, which shows expenses, revenue and profit. Also, it helps to control the budget by "identifying, collecting, analyzing, recording, and summarizing business transactions," and creates balance sheets of assets, liabilities, net assets and income tax reports (Byrnes 235). The last function in the business department is the Company Manager's department which is located at the production office and does the entire payroll, hiring process, complaints, contracts with vendors, record services and filings.

The artistic department (at the third level), in the organizational structure, consists of the Production Designers (lights, sound and scenery designers), the Musical Director and the Production Stage Manager. The Production Designers put together the artistic concept of the 
show following the Artistic Director's requests. The Musical Director is rehearsing and conducting the orchestra, singers and women's choir. He/she follows the Artistic Director requests by changing tempos and styles, and by acquiring and composing new parts. Also, he/she shares the information with his/her assistant, the women's choir conductor, who distributes and collects the sheet music from the orchestra and choir members and conducts the women's choir. The last manager (and his assistant) in the artistic management department is the Stage Manager or the Production Stage Manager (in large performances). He/she functions as a mediator between the artistic and managerial departments including the business department. $\mathrm{He} / \mathrm{she}$ prepares and distributes the production schedules and provides management with the artistic requests and their projected expenses. Also, the Stage Manager rephrases the Artistic Director's requests to a technical language, so technicians will understand immediately what is needed to be done. Some of his/her tasks are to call the show, to prepare a prompt book (with all the technical cues), and to control all the procedures for the show.

The fourth tier of the structure contains the operational management and its labor. Craftsmen, actors and musicians are to execute the show while their line mangers comply with deadlines and are pressured to finish all the artistic crafts and preparations. Examples for line mangers are Assistant Stage Manager, Crew Chief, Prop Master, Wardrobe Master and any technical studio's manager. The first to assist line managers are the crewmembers (scenic studio laborers, costume workshop artists, lighting rental technicians, sound rental technicians), musicians and actors. Though they are located at the bottom of the structure, their salaries are not necessarily low and do not reflect the hierarchical levels within the company. 


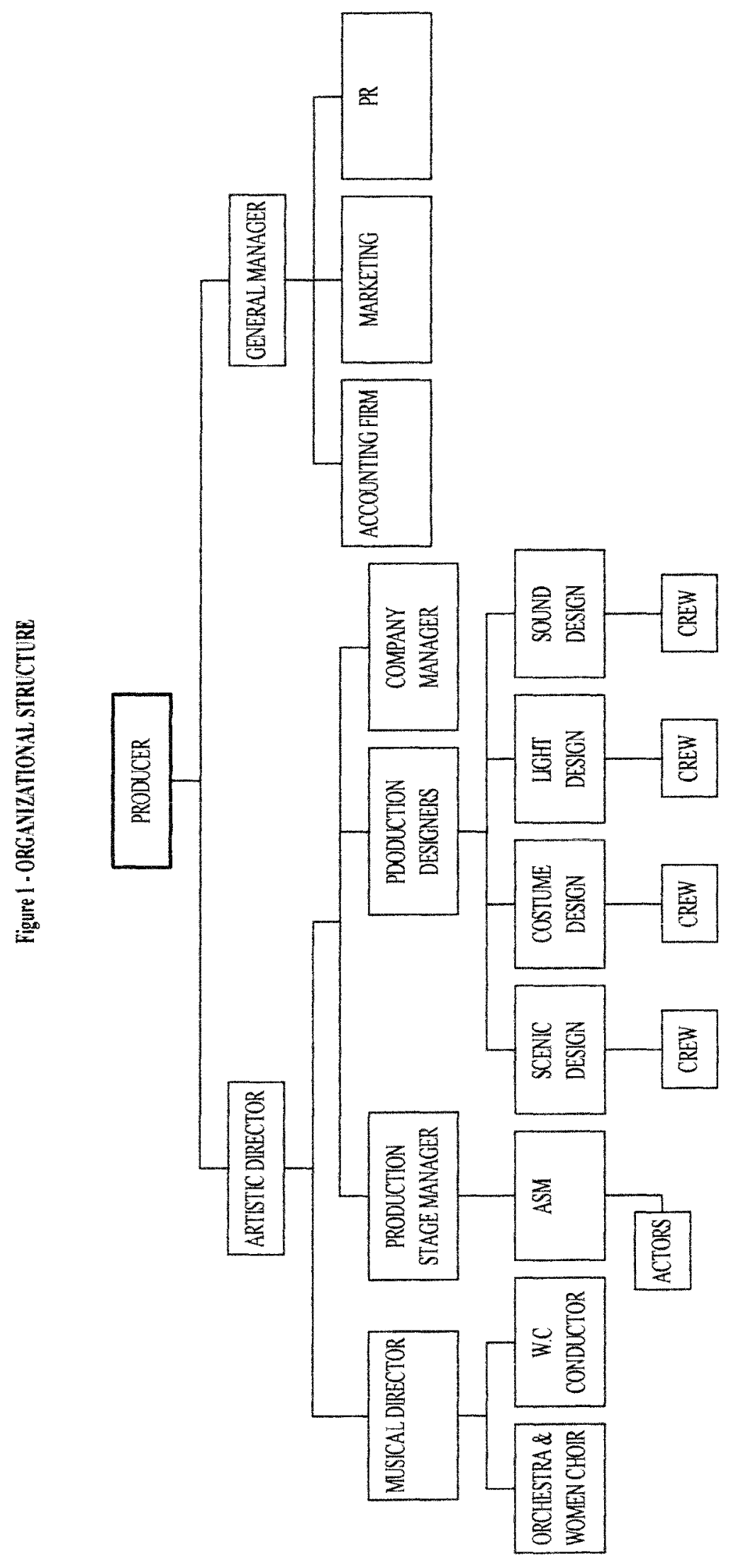

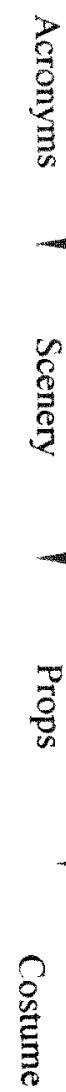

$\frac{5}{\frac{10}{6}}$

$\mathscr{E}$
$\Xi$
$\Xi$

$\frac{G}{\stackrel{g}{E}}$

$\frac{3}{3}$ 
While analyzing the organizational structure of "The Sound of Music", the Artistic Director figured more specifically which jobs are needed for the production and which tasks are to be executed. Also, by reading the script many times and preparing informative diagrams, the Stage Manager found many details such as the minimum cast and musicians to be hired, extra personnel such as Choreographer and Hairdressers, and more technical information that needs the assistance of certain jobs.

The careers involved in a musical touring show

The career opportunity within the "The Sound of Music" Musical Tour Show is divided between artistic careers and business opportunities. Artistic careers involve the show and its artistic center (music and theatre). Business opportunities involve promoting, marketing and managing the show and its personnel. The Artistic Director and the General Manager are also functioning as the human resources (H\&R) department. The H\&R department defines major functions for establishing job positions, lists specific duties for each job, analyzes duties and creates job descriptions. They get assistance from the company manager who processes the applications and advertises job openings. For both, the artistic and the business careers, there are specific demands and tasks. Below are the jobs and their respective descriptions for "The Sound of Music" musical production.

According to the play and the musical scripts of "The Sound of Music" the minimum necessary job descriptions that would operate this particularly researched production as a local touring musical are:

The Producer - stands at the top of the pyramid. He/she is the financial investor and the sponsors' leader. Also he/she supervises everything concerned with the production.

The Artistic Director - is the supervisor of the artistic show, its concept, designs, cast, rehearsals, costumes, sound, and light effects. Also he/she directs the play, approves the actors, scene design, costumes, and anything that contributes to the actual show. His/her most active 
responsibility is to conduct rehearsals in a manner of learning, polishing, and experimenting the performed script.

The General Manager - assists the producer in all matters involving marketing, public relations, accounting reports, payrolls, and contracts. Also he/she attends sponsorship presentations and assists with box office predictions.

The Marketing firm - conducts research and develops marketing plan, which includes television commercials, radio jingles, newspaper advertising, and direct mail.

The Public Relations firm - is responsible for all matters that relate to future and current publicity of the show including scheduling press presentations press releases, radio and newspaper interviews with actors, publish articles and television documentaries.

The Company Manager is the Producer's business representative in the organization. He/she takes care of the company. $\mathrm{He} / \mathrm{she}$ is in charge of managing the payroll, bookkeeping and administrative work. Also, he/she does the hotel bookings and helps to prevent personal discomforts.

The Support Personnel - are needed only on performance days. Usually they need to assist with different tasks such as custodians, parking attendants, security guards and ushers.

The Set Designer - is responsible to design all the settings and costumes for approval by the Artistic Director and Producer. He/she supervises the painting and construction of the settings and chooses the required furnishings.

The Musical Director/ Orchestra Conductor - selects musicians, rehearses with soloists and orchestra. Also, during the show, he/she has to follow the Stage Manager's sound cues. The Choral Conductor - distributes and collects sheet music to and from orchestra's musicians and women's chorale's singers, conducts the women's choral from back stage and has to watch the stage monitor and follow the Stage Manager's sound cues during performances. 
The Master Carpenter/Crew Chief - is responsible for setting the whole set and scenery including rigging, hanging, and movement. He/she executes the instructions from the hanging plot and set the final flying system to match instructed locations for drops, scenery, lights, curtains, and special effects. He/she decides on the working order to keep production smooth and safe.

The Crew (Stagehands) - during performances, they move sets in and out quietly and efficiently. They follow the Crew Chief's orders and operate the fly system. Before and after performances, they need to be able to work carefully for long hours; doing the loading in and the loading out sets of scenery and technical equipment.

The Chief Electrician - is responsible to set up and operate the lights for the show using the lighting designer's plot. Also, he/she prepares the lighting technical rider for a rental order from the lighting shop and makes sure all instruments match the design specifications. He/she checks venues for power supply sufficiency, installation and wiring of the sound equipment. Also, he/she is the one that hires one sound technician and two light operators. They will assist with hanging up lights and during performances they will operate the follow spotlights (FSLs). He/she must discuss with the Master Carpenter all hanging procedures including the insertion of color jells into the color frame holders.

The Sound Technician - supervises the preparation and installation of all sound equipment and making sure that all-internal sound communications such as Intercoms and headsets are functioning. During the show he/she has to operate sound track recordings and mute the unnecessary microphones to prevent feedback noises.

The Property Master - obtains the property list from the Stage Manager and succeeds to prepare it for the first rehearsal. Even when he/she is under time pressure he/she has to be an artisan and inventive as possible. He/she works closely with the Stage Manager on the set design locations, set up the property tables, which include the drafted lineout of all the necessary props on white 
sheet covers. Also, he/she helps to strength and secure furniture for the show and prepares hand properties.

The Wardrobe Master - constructs or rents the costumes according to the set designer. He/she will run costumes during the show with two dressers that he/she hires. One is male and the other is female. They will help actors to get in and out of costumes. Before the show he/she has to prepare the dressing space and wardrobe-hanging bars in the designated curtained dressing booths (men and women have separate ones).

The Hair Supervisors (4) - check that everyone's hair is satisfying the demands of the Artistic Director and the individual actor as well.

The Makeup Artists (4) - make up the actors according to the artistic design demands and to the Artistic Director and actor's satisfaction.

The Musicians - will be selected by the Musical Director through audition's process. The total of orchestra members is a minimum of 31 musicians. The orchestra includes: Flute I, Flute II (doubling Piccolo), Oboe (doubling English horn), Clarinet I, Clarinet II, Bassoon. Horn I, Horn II, Horn III, Trumpet I, Trumpet II, Trumpet III, Trombone I, Trombone II, Tuba, Percussion (1 player), Harp, Guitar (doubling mandolin), Violins I, Violins II, Violas, Cellos, and Bass (string complement 4-4-2-2-1). All musicians have to follow the Conductor and the Stage Manager's orders.

The Actors - will be selected by the Artistic Director through audition's process. The total cast is 33 actors (23 stars and costars and 10 extras). They include: Maria, Sister Berthe, Sister Margareta, Mother Abbess, Sister Sophia, Captain George von Trapp, Franz - the butler, Frau Schmidt - the housekeeper, Children of Captain von Trapp (Liesl, Friedrich, Louisa, Kurt, Brigitta, Marta, Gretl), Rolf Gruber, Max Detwieler. Extra 1: Herr Zeller (I: 11, II: 5) / Nazi man Postulant \#1 (I: 1, II: 2) /Trio/Nun \# 5. Extra 2: Baron Elberfeld/Postulant \#2 (I: 1, II: 2) Nun 6 (1: 12) / Nazi man /Trio. Extra 3: Admiral von Schreiber / Nazi men / Postulant 3 (1: 
1, II: 2) Party dancer/Trio. Extras 4 and 5: Understudies for Rolf, Max and the Captain/Party dancers Nuns \# 7, 8. Extra 6: Baroness Elberfeld (I: 11) Nun $\#$ (I: 1, 12,11:2, 4, 7). Extra 7: Understudy for Liesl / Nun $\# 2$ (I: 1, I2, II: 4, 7) / Postulant (young girl) / Ursula / Elsa

Schraeder. Extra 8: Nun \#3 (1: 1, 12, II:4,7) Party dancer. Extra 9: Nun \# 4 (1: 1, 12, II: 2, 4, 7) : Party dancer. Extra 10: Understudy for Maria Party dancer.

The Choreographer - teaches the actors to dance the Austrian traditional dances, conducts individual rehearsals, creates and supervises romantic dances for Maria and the Captain at Scene 10 and for Rolf and Liesl at Scene 6. Also, he/she creates and supervises the dances for Do-ReMi and My Favorite Things.

The Production Stage Manager - he/she is in charge of the stage department's organization and has the specialist's knowledge of the whole field of technical production (carpentry, electrical, properties and wardrobe). Also, his/her duties include managing the performance and operations of the production process.

The advantage of "The Sound of Music" organizational structure is "to engage the most appropriate people, facilities, and equipment to produce the play" (Ionazzi 157). The industry has proven time and time again that new hires become part of the organizational structure with much more ease due to the professional way of conducting the firm. Hiring and/or contracting over 100 employees, emphasizes the necessity to keep everything as simple as possible. If each one will do his/her job on the best side then everything else will go smooth and well. But still, there should be a responsible coordinator "the clearing house of information between the creative and the managerial forces" that will ensure the production's success by organizing information and supervising on the working procedures (Kelly 21). Who is this coordinator? Naturally, the only job that requires technical knowledge, managerial skills, artistic understanding, high communication skills, and sensitivity is the Production Stage Manager's job. 
CHAPTER III

\section{THE ESSENTIAL PRODUCTION STAGE MANAGER}

The appealing interest of the Production Stage Manager's position is that it involves many production fields. The creative field is very rewarding especially when the Artistic Director recognizes that the Production Stage Manager gets things done quickly. Since all creative decisions are the responsibility of the Artistic Director, the Production Stage Manager helps to solve, find, and maintain technical and artistic solutions. For instance, a new property request will be transmitted to the Property Master and the new property will arrive faster than expected. Also, fixing light effect or finding solution immediately for a technical problem might cause a positive feedback. Though those problems are most likely dependent on professional technicians, the Production Stage Manager knows were to communicate the request and oversees if it changes someone else's schedule. An example for this would be when the Artistic Director wants to move the sound console into the house for the purpose of having a better control over how the sound will be heard in the house. The Production Stage Manager contacts the box office and reserves those seats in the house before they will get sold. Coordinating this kind of tasks is just a small part of the managerial responsibilities that the Production Stage Manager has. In the management field, the Production Stage Manager also prepares the production schedule (see table 1) and distributes it to all production personnel. This task requires him/her to communicate and gather information from all departments involved in the show. 
Table 1 - PRODUCTION SCHEDULE - WEEK 1

\begin{tabular}{|c|c|c|c|c|c|c|}
\hline DAY & TIME & STATUS & EVENT & SITE & Act: Sc. & PERSONNEL NEEDED \\
\hline Mon & $8: 30-11: 30 \mathrm{am}$ & Reading & week 1 day 1 & Studio 1 & I: 5,6 , & Director, Children, Rolf, SM, Prop MA \\
\hline Mon & $12: 30-3: 00 \mathrm{pm}$ & Reading & week 1 day 1 & Studio 1 & & Musical director, Children + Rolf, SM \\
\hline Mon & $8: 30-11: 30 \mathrm{am}$ & Reading & week 1 day 1 & Studio 2 & $1: 2,3,4,7$ & Musical Director, Maria \\
\hline Mon & $12: 30-3: 00 \mathrm{pm}$ & Reading & week 1 day 1 & Studio 2 & I: 5 & Director, Max,Captain,FS, Maria \\
\hline Tue & $8: 30-11: 30 \mathrm{am}$ & Reading & week 1 day 2 & Studio 1 & I: 9,5 II:6 & Musical director, Family \\
\hline Tue & $12: 30-3: 00 \mathrm{pm}$ & Reading & week 1 day 2 & Studio 1 & I: 5,7 & Director, Family, FS \\
\hline Tue & $8: 30-11: 30 \mathrm{am}$ & Reading & week 1 day 2 & Studio 2 & $\mathrm{I}: 3, \mathrm{II}: 3,7$ & Director, SS, SM, SB, Ma \\
\hline Tue & $12: 30-3: 00 \mathrm{pm}$ & Reading & week 1 day 2 & Studio 2 & II: 4,7 & Musical director, All Nuns \\
\hline Wed & $8: 30-11: 30 \mathrm{am}$ & Reading & week 1 day 3 & Studio 1 & III: 1,6 & Musical director, Family, Max, ES \\
\hline Wed & $12: 30-3: 00 \mathrm{pm}$ & Reading & week 1 day 3 & Studio 1 & II: 1,6 & Director, Max, ES, Family, Franz \\
\hline Wed & $8: 30-11: 30 \mathrm{am}$ & Reading & week 1 day 3 & Studio 2 & I: 13 & Director, Ma, SM, SS, Postulant \\
\hline Wed & $12: 30-3: 00 \mathrm{pm}$ & Reading & week 1 day 3 & Studio 2 & I: $3,13, \mathrm{II}: 7$ & Musical director, $\mathrm{Ma}$ \\
\hline Thur & $8: 30-11: 30 \mathrm{am}$ & Reading & week 1 day 4 & Studio 1 & I: 5,6 & Director, Children + Rolf, SM \\
\hline Thur & $12: 30-3 ; 00 \mathrm{pm}$ & Reading & week 1 day 4 & Studio 1 & & Musical director, Children + Rolf, SM \\
\hline Thur & $8: 30-11: 30 \mathrm{am}$ & Reading & week 1 day 4 & Studio 2 & $1: 2,3,4,7$ & Musical Director, Maria \\
\hline Thur & $12: 30-3: 00 \mathrm{pm}$ & Reading & week 1 day 4 & Studio 2 & I: 5 & Director, Max, Captain,FS, Maria \\
\hline Fri & $8: 30-11: 30 \mathrm{am}$ & Reading & week 1 day 5 & Studio 1 & I: 9,5 II:6 & Musical director, Family \\
\hline Fri & $12: 30-3: 00 \mathrm{pm}$ & Reading & week 1 day 5 & Studio 1 & I: 5,7 , & Director, Maria, Children, FS, Captain \\
\hline Fri & $8: 30-11: 30 \mathrm{am}$ & Reading & week 1 day 5 & Studio 2 & $\mathrm{I}: 3, \mathrm{II}: 3,7$ & Director, SS, SM, SB, Ma \\
\hline Fri & $12: 30-3: 00 \mathrm{pm}$ & Reading & week 1 day 5 & Studio 2 & II: 4,7 & Musical director, All Nuns \\
\hline Sat & $8: 30-11: 30$ am & Reading & week 1 day 6 & Studio 1 & II: 1,6 & Musical director, Family, Max, ES \\
\hline Sat & $12: 30-3: 00 \mathrm{pm}$ & Reading & week 1 day 6 & Studio 1 & II: 1,6 & Director, Max, ES, Family, Franz \\
\hline Sat & $8: 30-11: 30 \mathrm{am}$ & Reading & week 1 day 6 & Studio 2 & I: $3,13,11: 7$ & Director, Ma, SM, SS, Postulant \\
\hline Sat & $12: 30-3: 00 \mathrm{pm}$ & Reading & week 1 day 6 & Studio 2 & I: 13 & Musical director, $\mathrm{Ma}$ \\
\hline Sun & off & off & off & off & off & off \\
\hline
\end{tabular}


PRODUCTION SCHEDULE - WEEK 2

\begin{tabular}{|c|c|c|c|c|c|c|}
\hline DAY & TIME & STATUS & EVENT & SITE & Act: $\mathrm{Sc}$. & PERSONNEL NEEDED \\
\hline Mon & $8: 30-11: 30 \mathrm{am}$ & Reading & week 2 day 1 & Studio 1 & $1: 1-3,4,12$ & Director Ma, SB, SM. SS, Maria, Extras \\
\hline Mon & $12: 30-3: 00 \mathrm{pm}$ & Reading & week 2 day 1 & Studio 1 & $\mathrm{I}: 13, \mathrm{II}: 2-4$ & Musical director, Sisters, Maria, Extras \\
\hline Mon & $8: 30-11: 30 \mathrm{am}$ & Reading & week 2 day 1 & Studio 2 & $\mathrm{I}: 11, \mathrm{II}: 1,5$ & Musical director, Maria \\
\hline Mon & $12: 30-3.00 \mathrm{pm}$ & Reading & week 2 day 1 & Studio 2 & $\mathrm{I}: 9, \mathrm{II}: 7,1$ & Director, Family, FS, Franz, ES, Max, Rolf \\
\hline Tue & $8: 30-11: 30 \mathrm{am}$ & Reading & week 2 day 2 & Studio 1 & I:9,5 II:6 & Musical director, Family \\
\hline Tue & $12: 30-3: 00 \mathrm{pm}$ & Reading & week 2 day 2 & Studio 1 & $1: 5,7$ & Director, Maria, Children, FS, Captain \\
\hline Tue & $8: 30-11: 30 \mathrm{am}$ & Reading & week 2 day 2 & Studio 2 & $1: 3,11: 3,7$ & Director, SS, SM, SB, Ma \\
\hline Tue & $12: 30-3: 00 \mathrm{pm}$ & Reading & week 2 day 2 & Studio 2 & II:4,7 & Musical director, All Nuns \\
\hline Wed & $8: 30-11: 30$ am & Reading & week 2 day 3 & Studio 1 & III: 1,6 & Musical director, Family, Max, ES \\
\hline Wed & $12: 30-3: 00 \mathrm{pm}$ & Reading & week 2 day 3 & Studio 1 & III: 1,6 & Director, Max, ES, Family, Franz \\
\hline Wed & $8: 30-11: 30 \mathrm{am}$ & Reading & week 2 day 3 & Studio 2 & I: 13 & Director, Ma, SM, SS, Postulant \\
\hline Wed & $12: 30-3: 00 \mathrm{pm}$ & Reading & week 2 day 3 & Studio 2 & $1: 3,13,11: 7$ & Musical director, $\mathrm{Ma}$ \\
\hline Thur & $8: 30-11: 30 a m$ & Reading & week 2 day 4 & Studio 1 & I:9,5 II:6 & Musical director, Family \\
\hline Thur & $12: 30-3: 00 \mathrm{pm}$ & Reading & week 2 day 4 & Studio 1 & $\mathrm{I}: 5,7$ & Director, Maria, Children, FS, Captain \\
\hline Thur & $8: 30-11: 30 \mathrm{am}$ & Reading & week 2 day 4 & Studio 2 & $1: 3,11: 3,7$ & Director, SS, SM, SB, Ma \\
\hline Thur & $12: 30-3: 00 \mathrm{pm}$ & Reading & week 2 day 4 & Studio 2 & II: 4,7 & Musical director, All Nuns \\
\hline Fri & $8: 30=11: 30 \mathrm{am}$ & PR Interviews & week 2 day 5 & Studio 1 & PR & Children, ASM \\
\hline Fri & $12: 30-3: 00 \mathrm{pm}$ & PR interviews & week 2 day 5 & Studio 1 & PR & Director \\
\hline Fri & $8: 30-11: 30 \mathrm{am}$ & Reading & week 2 day 5 & Studio 2 & I: 6 & Choreographer, ALl, Rolf \\
\hline Fri & $12: 30-3: 00 \mathrm{pm}$ & Reading & week 2 day 5 & Studio 2 & I:11 & Choreographer, Maria, Captain, Extras \\
\hline Sat & $8: 30-11: 30 \mathrm{am}$ & Read-through & week 2 day 6 & Studio 1 & $I+I I$ & Director, Musical director, Cast \\
\hline Sat & $12: 30-3: 00 \mathrm{pm}$ & Read-through & week 2 day 6 & Studio 1 & $I+I I$ & Director, Musical director, Cast \\
\hline Sat & $8: 30-11: 30 \mathrm{am}$ & PR interviews & week 2 day 6 & Studio 2 & PR & Choreographer, Maria, Captain, Extras \\
\hline Sat & $12: 30-3: 00 \mathrm{pm}$ & PR interviews & week 2 day 6 & Studio 2 & PR & Choreographer, Maria, Captain, Extras \\
\hline Sun & off & off & off & off & Loff & off \\
\hline
\end{tabular}




\section{PRODUCTION SCHEDULE - WEEK 3}

\begin{tabular}{|c|c|c|c|c|c|c|}
\hline DAY & TIME & STATUS & EVENT & SITE & Act: Sc. & PERSONNEL NEEDED \\
\hline Mon & $8: 30-11: 30 \mathrm{am}$ & Read-through & week 3 day 1 & Studio 1 & $I+I I$ & Director, Cast \\
\hline Mon & $12: 30-3: 00 \mathrm{pm}$ & Read-through & week 3 day 1 & Studio 1 & $I+I I$ & Director, Cast \\
\hline Mon & $8: 30-11: 30 \mathrm{am}$ & Reading & week 3 day 1 & Studio 2 & $1+11$ & Musical Director, Orch. \\
\hline Mon & $12: 30-3: 00 \mathrm{pm}$ & Reading & week 3 day 1 & Studio 2 & $I+I I$ & Musical Director, Orch. \\
\hline Tue & $8: 30-11: 30 \mathrm{am}$ & Psitioning & week 3 day 2 & Studio 1 & $I+I I$ & Choreographer, Cast \\
\hline Tue & $12: 30-3: 00 \mathrm{pm}$ & Positioning & week 3 day 2 & Studio 1 & $\mathrm{I}+\mathrm{II}$ & Choreographer, Cast \\
\hline Tue & $8: 30-11: 30 \mathrm{am}$ & Read-through & week 3 day 2 & Studio 2 & $\mathrm{I}+\mathrm{II}$ & Musical Director, Orch. \\
\hline Tue & $12: 30-3: 00 \mathrm{pm}$ & Read-through & week 3 day 2 & Studio 2 & $I+I I$ & Musical Director, Orch. \\
\hline Wed & $8: 30-11: 30 \mathrm{am}$ & Psitioning & week 3 day 3 & Studio 1 & $\sqrt{\mathrm{I}+\mathrm{II}}$ & Choreographer, Cast \\
\hline Wed & $12: 30-3: 00 \mathrm{pm}$ & Positioning & week 3 day 3 & Studio 1 & I + II & Choreographer, Cast \\
\hline Wed & $8: 30-11: 30 \mathrm{am}$ & Read-through & week 3 day 3 & Studio 2 & $\mathrm{I}+\mathrm{II}$ & Musical Director, Orch. \\
\hline Wed & $12: 30-3: 00 \mathrm{pm}$ & Read-through & week 3 day 3 & Studio 2 & $\mathrm{I}+\mathrm{II}$ & Musical Director, Orch. \\
\hline Thur & $9: 00-12: 00 \mathrm{pm}$ & Run through & week 3 day 4 & Studio 3 & I + II & Director, Musical director, Cast, Orch. \\
\hline Thur & $1: 00-3: 30$ & Run through & week 3 day 4 & Studio 3 & $\mathrm{I}+\mathrm{II}$ & Director, Musical director, Cast, Orch. \\
\hline Fri & $9: 00-12: 00 \mathrm{pm}$ & Run through & week 3 day 5 & Studio 3 & $\mathrm{I}+\mathrm{II}$ & Director, Musical director, Cast, Orch. \\
\hline Fri & $1: 00-3: 30$ & Run through & week 3 day 5 & Studio 3 & $\mathrm{I}+\mathrm{II}$ & Director, Musical director, Cast, Orch. \\
\hline Sat & $9: 00-12: 00 \mathrm{pm}$ & Run through & week 3 day 6 & Studio 3 & $\mathrm{I}+\mathrm{II}$ & Director, Musical director, Cast, Orch. \\
\hline Sat & $1: 00-3: 30$ & Run through & week 3 day 6 & Studio 3 & $I+I I$ & Director, Musical director, Cast, Orch. \\
\hline Sun & off & off & off & off & off & off \\
\hline
\end{tabular}




\section{PRODUCTION SCHEDULE - WEEK 4}

\begin{tabular}{|c|c|c|c|c|c|c|}
\hline DAY & TIME & STATUS & EVENT & SITE & Act: Sc. & PERSONNEL NEEDED \\
\hline $\begin{array}{l}\text { Mon } \\
\text { Mon }\end{array}$ & $\begin{array}{l}9: 00-12: 00 \mathrm{pm} \\
1: 00-3: 30 \\
\end{array}$ & $\begin{array}{l}\text { Run through } \\
\text { Positioning }\end{array}$ & $\begin{array}{l}\text { week } 4 \text { day } 1 \\
\text { week } 4 \text { day } 1 \\
\end{array}$ & \begin{tabular}{|l} 
Studio 2 \\
Studio 2 \\
\end{tabular} & $\begin{array}{l}I+I I \\
I+I I \\
\end{array}$ & $\begin{array}{l}\text { Director, Cast, Prop MA, Choreog. } \\
\text { Senery and L design, Cast, Choreog. }\end{array}$ \\
\hline $\begin{array}{l}\text { Tue } \\
\text { Tue }\end{array}$ & $\begin{array}{l}9: 00-12: 00 \mathrm{pm} \\
1: 00-3: 30 \\
\end{array}$ & $\begin{array}{l}\text { Polishing } \\
\text { Polishing }\end{array}$ & $\begin{array}{l}\text { week } 4 \text { day } 2 \\
\text { week } 4 \text { day } 2 \\
\end{array}$ & $\begin{array}{l}\text { Studio } 1 \\
\text { Studio } 1\end{array}$ & $\begin{array}{l}I+I I \\
I+I I\end{array}$ & $\begin{array}{l}\text { Individual cast members, Director } \\
\text { Cast members, Musical director }\end{array}$ \\
\hline Wed & 7:00am & Load in Senery & week 4 day 3 & Venue 1 & I+ II & Master carpenter, Crew \\
\hline $\begin{array}{l}\text { Thur } \\
\text { Thur }\end{array}$ & $\begin{array}{l}\text { 7:00am } \\
8: 00 \mathrm{pm}\end{array}$ & $\begin{array}{l}\text { Load in } \\
\text { Tech rehearsal }\end{array}$ & $\begin{array}{l}\text { week } 4 \text { day } 4 \\
\text { week } 4 \text { day } 4\end{array}$ & $\begin{array}{l}\text { Venue } 1 \\
\text { Venue } 1\end{array}$ & $\begin{array}{l}I+I I \\
I+I I\end{array}$ & $\begin{array}{l}\mathrm{L} \text { and sound designers, crew, Carpenter } \\
\text { Every one (Cast, Crew, Technicians) }\end{array}$ \\
\hline Fri & $7: 00 \mathrm{pm}$ & Dress rehearsal & week 4 day 5 & Venue 1 & $\mathrm{I}+\mathrm{II}$ & Every one (Cast, Crew, Technicians) \\
\hline $\begin{array}{l}\text { Sat } \\
\text { Sat }\end{array}$ & $\begin{array}{l}1: 00-4: 00 \mathrm{pm} \\
8: 00-11: 00 \mathrm{pm} \\
\end{array}$ & $\begin{array}{l}\text { Show time } \\
\text { Show time }\end{array}$ & $\begin{array}{l}\text { week } 4 \text { day } 6 \\
\text { week } 4 \text { day } 6 \\
\end{array}$ & \begin{tabular}{|l|} 
Venue 1 \\
Venue 1 \\
\end{tabular} & $\begin{array}{l}I+I I \\
I+I I\end{array}$ & $\begin{array}{l}\text { Every one (Cast, Crew, Technicians) } \\
\text { Every one (Cast, Crew, Technicians) }\end{array}$ \\
\hline $\begin{array}{l}\text { Sun } \\
\text { Sun }\end{array}$ & $\begin{array}{l}2: 00-5: 00 \mathrm{pm} \\
6: 00 \mathrm{pm}-\end{array}$ & $\begin{array}{l}\text { Show time } \\
\text { strike \& loadout }\end{array}$ & $\begin{array}{l}\text { week } 4 \text { day } 7 \\
\text { week } 4 \text { day } 7\end{array}$ & \begin{tabular}{|l|} 
Venue 1 \\
Venue 1 \\
\end{tabular} & $\begin{array}{l}\mathrm{I}+\mathrm{II} \\
\mathrm{I}+\mathrm{II}\end{array}$ & $\begin{array}{l}\text { Every one (Cast, Crew, Technicians) } \\
\text { Crew, Technicians }\end{array}$ \\
\hline Mon & off & off & off & off & off & off \\
\hline Tue & off & off & off & off & off & off \\
\hline
\end{tabular}


PRODUCTION SCHEDULE - WEEK 5 - 6

\begin{tabular}{|c|c|c|c|c|c|c|}
\hline DAY & TIME & STATUS & EVENT & SITE & Act: Sc. & PERSONNEL NEEDED \\
\hline Wed & 7:00am & Load in Senery & week 5 day 3 & Venue 2 & $1+11$ & Master carpenter, Crew \\
\hline Thur & 7:00am & Load in & week 5 day 4 & Venue 2 & $I+11$ & $\mathrm{~L}$ and $\mathrm{S}$ designers, crew, Carpenter \\
\hline Thur & $8: 00 \mathrm{pm}$ & Tech rehearsal & week 5 day 4 & Venue 2 & $\mathrm{I}+\mathrm{II}$ & Every one (Cast, Crew, Technicians) \\
\hline Fri & 7:00pm & Dress rehearsal & week 5 day 5 & Venue 2 & $1+11$ & Every one (Cast, Crew, Technicians) \\
\hline Sat & $1: 00-4: 00 \mathrm{pm}$ & Show time & week 5 day 6 & Venue 2 & $I+I I$ & Every one (Cast, Crew, Technicians) \\
\hline Sat & $8: 00-11: 00 \mathrm{pm}$ & Show time & week 5 day 6 & Venue 2 & $I+I I$ & Every one (Cast, Crew, Technicians) \\
\hline Sun & $2: 00-5: 00 \mathrm{pm}$ & Show time & week 5 day 7 & Venue 2 & $I+I I$ & Every one (Cast, Crew, Technicians) \\
\hline Sun & $6: 00 \mathrm{pm}-$ & strike \& loadout & week 5 day 7 & Venue 2 & $1+11$ & Crew, Technicians \\
\hline Mon & off & off & off & off & off & off \\
\hline Tue & off & off & off & off & off & off \\
\hline Wed & 7:00am & Load in Senery & week 6 day 3 & Venue 3 & $1+11$ & Master carpenter, Crew \\
\hline Thur & 7:00am & Load in & week 6 day 4 & Venue 3 & $I+11$ & $\mathrm{~L}$ and $\mathrm{S}$ designers, crew, Carpenter \\
\hline Thur & 8:00pm & Tech rehearsal & week 6 day 4 & Venue 3 & $I+I I$ & Every one (Cast, Crew, Technicians) \\
\hline Fri & 7:00pm & Dress rehearsal & week 6 day 5 & Venue 3 & I + II & Every one (Cast, Crew, Technicians) \\
\hline Sat & $1: 00-4: 00 \mathrm{pm}$ & Show time & week 6 day 6 & Venue 3 & $\mathrm{I}+\mathrm{II}$ & Every one (Cast, Crew, Technicians) \\
\hline Sat & $8: 00-11: 00 \mathrm{pm}$ & Show time & week 6 day 6 & Venue 3 & $\mathrm{I}+\mathrm{II}$ & Every one (Cast, Crew, Technicians) \\
\hline Sun & $2: 00-5: 00 \mathrm{pm}$ & Show time & week 6 day 7 & Venue 3 & $\mathrm{I}+\mathrm{II}$ & Every one (Cast, Crew, Technicians) \\
\hline Sun & 6:00pm - & strike \& loadout & week 6 day 7 & Venue 3 & $I+I I$ & Crew, Technicians \\
\hline
\end{tabular}


There are so many odds and bits that could be added to a good and experienced

Production Stage Manager's agenda, but the plenty and essential job requirements must be listed in order to prevent miscommunications within the organization and potential forgotten tasks.

Therefore defining the exact duties of the Production Stage Manager in "The Sound of Music" musical touring company, is essential to the pre, during and postproduction stages.

\section{The Production Stage Manager's duties}

At the pre production stage the Production Stage Manager collects and distributes technical, artistic, managerial, and personal information. Also, he/she manages rehearsals and technical operations.

The first duty is to prepare and distribute a contact sheet with a list of "cast, designers, crew, [food providers, public transportation, hotels, music stores] and anyone ells needed to be contacted about the show. It should include work and home phone numbers, fax numbers," cellular phone numbers, emails, and addresses (Campbell 168).

The second duty is to organize production meetings with the presence of all line managers. The production meetings share logistical information such as design preparation's deadlines and progress, space, dimensions and budget. They should be short and informative. Longer discussions on specific issues should be done in smaller conferences.

The third duty is to prepare and distribute lists of information that will help everyone in the production (see CHAPTER IV). Lists such as: costumes, properties, scenery breakdown to actors and solos, light and sound cue shifts and requirements. Also a first draft of the production schedule should be prepared and distributed. The production schedule contains everything that is involved in the production. Also, a revised schedule with new deadlines and changes should be distributed and posted.

The fourth duty is to keep a Stage Manager's book (see CHAPTER IV). All the information that the Production Stage Manager collected and prepared should be there. Also, the 
prompt script must be there as well. The prompt script should be well prepared so even if the Production Stage Manager is removed, for some reason, the Assistant Stage Manager will be able to run the show and call all the necessary cues. The prompt script has the original script along with cues of sound, lights, curtains, scene changes, and other elements that has to happen during a show. Almost every cue has a warning and a note that describes the specifics of that cue. The preparation of the prompt script is done by: reading the script through and then reading it again while breaking it down to notes and cues to be read in the order the show will be performed. This is the key for successful production. It requires the most comprehensive analysis of the script, score and performance.

The fifth duty is to manage auditions and rehearsals - during the pre production stage and prior to the audition process, the Production Stage Manager starts his/her professional relationship with actors and artists. He/she prepares the space and its illuminations, reserves extra waiting rooms, and posts helpful signs to find the appropriate rooms. He/she also distributes an information sheet about the production and the audition process, and masks the best acoustical and visual spot to stand on during the audition. For rehearsals, the Production Stage Manager should distribute rehearsal schedule, contact sheets, and scripts. Also, he/she should be "on book once the actors are off book [and reciting the lines]" from memory (Campbell 179). Being on book saves rehearsal time by providing actors with lines, which they forgot, from the play script.

The sixth duty is to prepare and post rehearsal reports - It is vital to be specific and write short critical informative comments for each specific department. The information should include changing needs and potential problems divided into areas such as: sound, lights, costumes, properties, scenery, actors, musicians, and miscellaneous. This assists the Production Stage Manager to succed in getting the information through. Otherwise, employees might lose concentration and patience while reading through the whole report. 
The seventh duty is to coordinate schedules for load-ins and outs (get an idea from the Master Carpenter of how much time is needed), technical rehearsals, costume fittings, and special rehearsals.

The eighth duty is to conduct a Cue to Cue rehearsal $(\mathbf{Q} 2 \mathbf{Q})-$ actors will run through the show "only performing the lines right before and after a technical cue"(Campbell 182). The Production Stage Manager needs to prompt the actor to stop after each cue and then he asks from the director for feedback. If the cue was satisfactory then the Production Stage Manager go on to the next cue by finding a line in the script thirty second prior to the next cue and asking the actor to skip and wait until he will hear the "please go ahead" signal.

The ninth duty is running the show - The Production Stage Manager's first call is halfhour before the show begins. He/she makes sure with the House Manager, actors, technicians, crew and orchestra that they are ready to start the show. Then, he/she announces to close house and prompt the cues of the show.

The tenth duty is to conduct a postmortem - after the show is over, he/she will thank everyone and will keep some remarks to be posted as a performance report (which is similar to a rehearsal report). As important, he/she should define which comments to keep for crew and cast discussions and which to discuss privately.

Usually, changes are being made through out the production process. The Production Stage Manager is not only the right and left hands of the Artistic Director and the Producer but also a leader, chancellor, politician and motivator. To keep all his duties organized and well managed it is very important for him to acquire a well-prepared Stage Manager's book.

The Stage Manager's book also includes technical important information to communicate with the crew, lighting technician, sound technician, wardrobe master, prop master and costume designer. In "The Sound of Music" - Stage Manager's book there are different forms that process the data from the core script into an well-organized and clear information. The following Stage 
Manager's book is the essence of the research and it shows the details to be executed in order to pursue "The Sound of Music" musical touring show. 


\section{CHAPTER IV}

\section{"THE SOUND OF MUSIC" - STAGE MANAGER'S BOOK}

This book is the essence element and the core concept of the thesis. Creating this book took long days and hours of readings, analyzing information, and editing preparations. It analyzes consecutively (along the play script and the musical score) technical, logistical, and designing requirements. Those analyzing documentation assist the Production Stage Manager to manage a successful musical production.

Technical requirements such as sound and lights equipment are organized in lists according to each scene of the musical. Also, the technical rider lists instruments and technical requirements. Logistical requirements are divided to matrixes of scenery (set designs, solos of singing and dancing, list of actors in each scene) and production schedule. The production schedule includes times for rehearsals, technical rehearsals, loading in and out scenery and technical equipment to and from performing arts venues. The design requirements are expressed and listed through ground plans (list of AutoCAD drawings for each scene), costume and property lists that are written for each scene in the musical show.

Not only will this book assist the Production Stage Manager in controlling the production process through information lists, but it will also assist the Production Stage Manager in running the show through the prepared prompt script. The prompt script contains the script of the musical along with lists of technical cues for the sound operator, orchestra and choir's conductors, light operator and crew. By commanding the cues on time and executing them in a precise matter, the show will go as smooth as possible. 